University of Nebraska - Lincoln

DigitalCommons@University of Nebraska - Lincoln

3-2009

\title{
Evapotranspiration of irrigated and rainfed maize-soybean cropping systems
}

Andrew E. Suyker

University of Nebraska - Lincoln, asuyker1@unl.edu

Shashi Verma

University of Nebraska - Lincoln, sverma1@unl.edu

Follow this and additional works at: https://digitalcommons.unl.edu/natrespapers

Part of the Natural Resources and Conservation Commons

Suyker, Andrew E. and Verma, Shashi, "Evapotranspiration of irrigated and rainfed maize-soybean cropping systems" (2009). Papers in Natural Resources. 197.

https://digitalcommons.unl.edu/natrespapers/197

This Article is brought to you for free and open access by the Natural Resources, School of at DigitalCommons@University of Nebraska - Lincoln. It has been accepted for inclusion in Papers in Natural Resources by an authorized administrator of DigitalCommons@University of Nebraska - Lincoln. 
Published in Agricultural and Forest Meteorology 149:3-4 (March 11, 2009), pp. 443-452; doi:10.1016/j.agrformet.2008.09.010

Published by Elsevier Ltd. Used by permission. http://www.elsevier.com/locate/agrformet

Submitted December 16, 2007; revised July 6, 2008; accepted September 22, 2008; published online November 5, 2008.

\title{
Evapotranspiration of irrigated and rainfed maize-soybean cropping systems
}

\author{
Andrew E. Suyker and Shashi B. Verma \\ School of Natural Resources, University of Nebraska-Lincoln, Lincoln, NE 68583-0978, USA \\ Corresponding author - A. E. Suyker, School of Natural Resources, 806 Hardin Hall, University of Nebraska, \\ Lincoln, NE 68583-0968, USA; tel 402 472-2168, fax 402 472-2946, email asuyker@unl.edu
}

\begin{abstract}
We have been making year-round measurements of mass and energy exchange in three cropping systems: (a) irrigated continuous maize, (b) irrigated maize-soybean rotation, and (c) rainfed maize-soybean rotation in eastern Nebraska since 2001. In this paper, we present results on evapotranspiration (ET) of these crops for the first 5 years of our study. Growing season ET in the irrigated and rainfed maize averaged 548 and $482 \mathrm{~mm}$, respectively. In irrigated and rainfed soybean, the average growing season ET was 452 and $431 \mathrm{~mm}$, respectively. On average, the maize ET was higher than the soybean ET by $18 \%$ for irrigated crops and by $11 \%$ for rainfed crops. The mid-season crop coefficient $K_{\mathrm{c}}\left(=\mathrm{ET} / \mathrm{ET}_{0}\right.$ and $\mathrm{ET}_{0}$ is the reference ET) for irrigated maize was 1.03 \pm 0.07 . For rainfed maize, significant dry-down conditions prevailed and mid-season $K_{c}$ was $0.84 \pm 0.20$. For irrigated soybean, the mid-season $K_{c}$ was $0.98 \pm 0.02$. The mid-season dry down in rainfed soybean years was not severe and the $K_{c}(0.90 \pm 0.13)$ was only slightly lower than the values for the irrigated fields. Non-growing season evaporation ranged from 100 to $172 \mathrm{~mm}$ and contributed about 16-28\% of the annual ET in irrigated/rainfed maize and $24-26 \%$ in irrigated/rainfed soybean. The amount of surface mulch biomass explained $71 \%$ of the variability in non-growing season evaporation totals. Water use efficiency (or biomass transpiration efficiency), defined as the ratio of total plant biomass $\left(Y_{\mathrm{DM}}\right)$ to growing season transpiration $(T)$ was $5.20 \pm 0.34$ and $5.22 \pm 0.36 \mathrm{~g} \mathrm{~kg}^{-1}$, respectively for irrigated and rainfed maize crops. Similarly, the biomass transpiration efficiency for irrigated and rainfed soybean crops was $3.21 \pm 0.35$ and $2.96 \pm 0.30 \mathrm{~g} \mathrm{~kg}^{-1}$. Thus, the respective biomass transpiration efficiency of these crops was nearly constant regardless of rainfall and irrigation.
\end{abstract}

Keywords: evapotranspiration, crop coefficient, water use efficiency, maize, corn, soybean, irrigation, rainfed

\section{Introduction}

Water and its movement through the soil-plant-atmosphere continuum is one of the most important factors affecting crop productivity (e.g., Boyer, 1982). For maize-soybean systems, extensive research has been conducted on the impact of water-related stress on crop development and yield (e.g., Denmead and Shaw, 1960; Musick and Dusek, 1980). The importance of evapotranspiration (ET) as a major com- ponent of the agricultural water budget increases as water resources become limiting due to factors such as (a) potential climate change, (b) population growth, (c) competition from other water users, (d) drought, and (e) water quality degradation (e.g., Farahani et al., 2007). Furthermore, large evapotranspiration rates in agricultural regions can be an important factor which influences the regional climate (e.g., Shukla and Mintz, 1982). Future climatic conditions are likely to lead to an increase in evapotranspiration causing regional soil 
moisture deficits in the Midwest (e.g., Easterling and Karl, 2001), thus affecting crop production in the region [ http:// www.gcrio.org/CONSEQUENCES/summer95/agriculture. $\underline{\mathrm{html}}]$.

In recent years, widespread droughts have been reported in the Great Plains [ http://lwf.ncdc.noaa.gov/oa/reports/ billionz.html\#chron ]. During the past 7 years, Nebraska has been experiencing local and regional drought conditions [ http://www.hprcc.unl.edu/nebraska/nebraska--JAN1999AUG2006 drought.html ]. In 2006, a severe spring/summer drought centered over the Great Plains region caused an estimated 6 billion dollars in damages. Such drought conditions put a great deal of stress on water resources in agricultural areas of the Midwest, especially irrigated regions through decreased water supply and greater pumping costs (e.g., Bowman and Collins, 1987).

In view of potential future shortages of water needed for agricultural production, more attention needs to be given to quantifying and improving water use efficiency (WUE). The WUE is generally defined (e.g., Steduto, 1996) as the ratio of biomass (or yield or photosynthesis) to water consumed in transpiration (or evapotranspiration). Because of the multiple ways WUE has been used in the literature, caution should be exercised in comparing results from different studies. Different soil/crop management practices are being assessed to improve water use efficiency in crop production (e.g., Hatfield et al., 2001). No-till management practices and better crop residue management can potentially reduce water lost through soil evaporation (e.g., Wilhelm et al., 2004; Ji and Unger, 2001; Sauer et al., 1998).

Recent studies have pointed out the important roles of the non-growing season or fallow periods in relation to the flow of energy, carbon and water in agricultural ecosystems (Kucharik and Twine, 2007). Such analyses are crucial in view of the globally expanding biofuel industry. For example, the USDA ARS has initiated studies [ http://www.ars. usda.gov/research/projects/projects.htm?ACCN NO=4106 53\&showpars=true\&fy=2006 ] with key objectives of determining sustainable removal of residues that would otherwise be left in the field so as not to (a) degrade the productivity of the land, (b) decrease soil organic matter, (c) diminish water quality, or (d) result in net carbon emissions (Graham et al., 2007). Long-term, continuous field measurements of mass and energy exchange are needed in agricultural crops with contrasting management practices to enhance our knowledge of evapotranspiration to help address these issues of significant scientific and economic importance.

Here we discuss year-round eddy covariance flux measurements of water vapor in three cropping systems (irrigated continuous maize, irrigated maize-soybean rotation, and rainfed maize-soybean rotation) in eastern Nebraska over a 5-year period. The primary objective of this study is to quantify evapotranspiration in these key agroecosystems and evaluate the contributions of growing season and nongrowing season periods to the annual ET totals. Growing season distributions of the crop coefficient $\left(K_{c}\right)$ are quantified. The role of surface mulch biomass is considered in examining the interannual variability of non-growing season evaporation. Also, water use efficiency of these crops is quantified.

\section{Materials and methods}

\subsection{Study sites}

The three study sites are located within $1.6 \mathrm{~km}$ of each other at the University of Nebraska Agricultural Research and Development Center near Mead, NE. These sites are large production fields, each 49-65 ha, that provide sufficient upwind fetch of uniform cover required for adequately measuring mass and energy fluxes using tower eddy covariance systems. One site (ICM: $41^{\circ} 09^{\prime} 54.2^{\prime \prime} \mathrm{N}, 9^{\circ} 28^{\prime} 35.9^{\prime \prime} \mathrm{W}, 361 \mathrm{~m}$ ) is equipped with center pivot irrigation and is planted in continuous maize. The second site (IMS: $41^{\circ} 09^{\prime} 53.5^{\prime \prime} \mathrm{N}, 96^{\circ} 28^{\prime} 12.3^{\prime \prime} \mathrm{W}$, $362 \mathrm{~m}$ ), also equipped with center pivot irrigation is planted in maize-soybean rotation. The third site (RMS: $41^{\circ} 10^{\prime} 46.8^{\prime \prime} \mathrm{N}$, $96^{\circ} 26^{\prime} 22.7^{\prime \prime} \mathrm{W}, 362 \mathrm{~m}$ ) relies on rainfall and is planted in maizesoybean rotation. Prior to initiation of the study, the irrigated sites (ICM and IMS) had a 10-year history of maize-soybean rotation under no-till. The rainfed site (RMS) had a variable cropping history of primarily wheat, soybean, oats, and maize grown in 2-4 ha plots with tillage. All three sites were uniformly tilled by disking prior to the beginning of the study to homogenize the top $0.1 \mathrm{~m}$ of soil and incorporate $\mathrm{P}$ and $\mathrm{K}$ fertilizers, as well as previously accumulated surface residues. The soils are deep silty clay loams, typical of eastern Nebraska, consisting of four soil series at all three sites: Yutan (fine-silty, mixed, superactive, mesic Mollic Hapludalfs), Tomek (fine, smectitic, mesic Pachic Argialbolls), Filbert (fine, smectitic, mesic Vertic Argialbolls), and Filmore (fine, smectitic, mesic Vertic Argialbolls).

Since initiation in 2001, all fields have been under no-till (except ICM in 2005). Crop management practices (i.e., plant populations, herbicide and pesticide applications, irrigation) have been employed in accordance with standard best management practices (BMPs) prescribed for production-scale maize-soybean systems. Results from the first 4 years documented declining yields with continuous irrigated maize (ICM) because of difficulties in achieving uniform and adequate plant populations due to the heavy litter layer that impeded the sowing operation, greater immobilization of fertilizer $\mathrm{N}$ reducing fertilizer $\mathrm{N}$ use efficiency, and increasing incidence and severity of insect and disease damage. The latter is a common problem in continuous maize that is worsened when large amounts of crop residue litter remains on the soil surface (e.g., Bockus and Shroyer, 1998; Steffey et al., 1999). To address these constraints in our continuous irrigated maize system (ICM), starting in the autumn of 2005, we began to utilize a conservation-plow that does not completely invert the topsoil layer as happens with conventional plowing. The conservation-plow minimizes soil disturbance by vertically distributing about $2 / 3$ of the crop residue within the surface $0.2-0.25 \mathrm{~m}$ depth, while $1 / 3$ remains on the soil surface. A small dose of $\mathrm{N}$ fertilizer is applied to the maize residue before the post harvest conservation-plowing operation. Table 1 summarizes major crop management information (including the dates of planting and harvest, cultivars planted, mulch biomass, and crop yields) for the study period. Following best management practices, to account for differences in water-limited attainable yield, lower planting densities were used in rainfed crops (RMS) as compared to 
the irrigated crops (ICM and IMS). Nitrogen (N) was applied in the irrigated maize in three applications and a single $\mathrm{N}$ fertilizer application was made to maize in the rainfed system. No additional $\mathrm{N}$ was applied in the soybean years in 2002 and 2004.

\subsection{Eddy covariance flux measurements}

Our measurements began just after planting time in 2001. Eddy covariance measurements (e.g., Baldocchi et al., 1988) of fluxes of latent heat (LE), sensible heat $(H)$, and momentum were made using the following sensors at each site: an omnidirectional 3D sonic anemometer (Model R3: Gill Instruments Ltd., Lymington, UK), and an open-path infrared $\mathrm{CO}_{2} / \mathrm{H}_{2} \mathrm{O}$ gas analyzing system (Model LI7500: Li-Cor Inc., Lincoln, NE). To have sufficient fetch (in all directions) representative of the cropping systems being studied, the eddy covariance sensors were mounted $3.0 \mathrm{~m}$ above the ground when the canopy was shorter than $1 \mathrm{~m}$, and later moved to a height of $6.0 \mathrm{~m}$ until harvest (maize only). Fluxes were corrected for inadequate sensor frequency response (Moore, 1986; Massman, 1991; Suyker and Verma, 1993]; in conjunction with cospectra calculated from this study). Fluxes were adjusted for the variation in air density due to the transfer of water vapor and sensible heat (e.g., Webb et al., 1980). More details of the measurements and calculations are given in a previous paper (Suyker et al., 2003). Air temperature and humidity (3.0 and $6.0 \mathrm{~m}$; Humitter50Y, Vaisala, Helsinki, FIN), net radiation at $5.5 \mathrm{~m}$ (CNR1, Kipp and Zonen Ltd., Delft, NLD), and soil heat flux (0.06 m depth; Radiation \& Energy Balance Systems Inc., Seattle, WA) were also measured.

To fill in missing data due to sensor malfunction, power outages, unfavorable weather, etc. (approximately 15-20\% per year), we adopted an approach that combined measurement, interpolation, and empirical data synthesis (e.g., Kim et al., 1992; Wofsy et al., 1993; Baldocchi et al., 1997; Suyker et al., 2003). When hourly values were missing (day or night), the LE was estimated as a function of available energy. Linear regressions between LE and available energy were determined (separately for dry and wet conditions) for sliding 3day intervals, and used to fill in missing flux values.

It is customary to compare the sum of latent and sensible heat fluxes $(\mathrm{LE}+\mathrm{H})$ measured by eddy covariance against the sum of $R_{\mathrm{n}}$ (net radiation) + storage terms, measured by other methods. As Meyers and Hollinger (2004) point out, the combination of soil and canopy heat storage and the energy used in photosynthesis of maize and soybean need to be considered for an accurate estimation of the energy balance closure. We calculated linear regressions between the hourly values of $H+L E$ and $R_{\mathrm{n}}+G$ at our study sites (excluding winter months and periods with rain and irrigation). Here $G=G_{\mathrm{s}}$ (soil heat storage) $+G_{\mathrm{c}}$ (canopy heat storage) $+G_{\mathrm{m}}$ (heat stored in the mulch) $+G_{p}$ (energy used in photosynthesis). These terms were roughly estimated using procedures similar to those outlined in Meyers and Hollinger (2004). The regression slopes at the three sites averaged $0.89 \pm 0.08$, implying a fairly good closure of the energy balance at our study sites.

\subsection{Leaf area and mulch biomass}

Leaf area was measured destructively at six different locations for $1 \mathrm{~m}$ linear row sections approximately on a bimonthly basis. The cubic spline method was used to interpolate daily values. To estimate the surface mulch biomass, we used information developed in a concurrent study (A. Kochsiek, University of Nebraska, personal communication; Verma et al., 2005) in which biomass, left as stover following harvest, was measured each year and exponential decay rates for all components (stalks, stems, husks, seed pods, etc.) were estimated. Following the 2005 post-harvest conservation plowing, we assumed $30 \%$ of the accumulated harvested biomass was still present on the surface [ http:// www.ncsu.edu/sustainable/tillage/tillage.html ].

Table 1. Crop management details, mulch biomass, and grain yield for the three sites during 2001-2005 (M - maize; S - soybean). Grain yield was adjusted to $0 \%$ moisture content.

\begin{tabular}{|c|c|c|c|c|c|c|}
\hline Site/year & Crop/cultivar & $\begin{array}{l}\text { Plant population } \\
\quad\left(\text { plants } \mathrm{ha}^{-1}\right)\end{array}$ & $\begin{array}{c}\text { Planting } \\
\text { date }\end{array}$ & $\begin{array}{c}\text { Harvest } \\
\text { date }\end{array}$ & $\begin{array}{l}\text { mass } \\
\left.a^{-1}\right)\end{array}$ & $\begin{array}{l}\text { Grain yield } \\
\qquad\left(\mathrm{Mg} \mathrm{ha}^{-1}\right)\end{array}$ \\
\hline \multicolumn{7}{|c|}{ Irrigated maize-soybean rotation (IMS) } \\
\hline 2001 & M/Pioneer 33P67 & 82,000 & May 10 & October 18 & 0.91 & 11.41 \\
\hline 2003 & M/Pioneer 33B51 & 77,000 & May 15 & October 27 & 1.60 & 10.24 \\
\hline 2004 & M/Pioneer 33B51 & 79,800 & May 3 & October 15 & 1.61 & 10.34 \\
\hline 2005 & M/Dekalb 63-75 CRW & 70,800 & May 4 & October 13 & 0.52 & 10.16 \\
\hline 2001 & $\mathrm{M} /$ Pioneer 33P67 & 80,900 & May 11 & October 22 & 0.86 & 11.33 \\
\hline 2002 & S/Asgrow 2703 & 333,100 & May 20 & October 7 & 0.95 & 3.47 \\
\hline 2003 & M/Pioneer 33B51 & 78,000 & May 14 & October 23 & 1.34 & 11.83 \\
\hline 2004 & S/Pioneer 93B09 & 296,100 & June 2 & October 18 & 1.02 & 3.23 \\
\hline 2005 & M/Pioneer 33B51 & 81,000 & May 2 & October 17 & 1.32 & 11.19 \\
\hline 2004 & S/Pioneer 93B09 & 264,700 & June 2 & October 11 & 0.60 & 2.97 \\
\hline 2005 & M/Pioneer 33G68 & 56,300 & April 26 & October 17 & 0.99 & 7.69 \\
\hline
\end{tabular}




\section{Results and discussion}

\subsection{Weather conditions and leaf area}

During the growing season (May-September), mean monthly air temperatures (Figure 1A) were generally within $1{ }^{\circ} \mathrm{C}$ of the 30-year climate normal (measured at a nearby weather station near Mead, NE; 1971-2000 Climate Normals; HPRCC, 2006), but typically tended to be warmer. The winter months were generally warmer $\left(1-5^{\circ} \mathrm{C}\right)$ than normal.

Precipitation (290-350 $\mathrm{mm}$ ) received at the three sites during the growing seasons of 2002, 2003, and 2005 (Table 2; Figure 1B) was significantly below the $450 \mathrm{~mm}$ normal (19712000 Climate Normals; HPRCC, 2006). In 2001 and 2004, the precipitation amounts (about $400-426 \mathrm{~mm}$ ) were only slightly below normal. Irrigation totals ranged from 230 to $350 \mathrm{~mm}$ in maize years and from 185 to $210 \mathrm{~mm}$ in soybean years.

Seasonal distributions of green leaf area index (LAI) are presented in Figure 2. The peak LAI of irrigated maize (ICM and IMS) ranged from 4.9 to $6.4 \mathrm{~m}^{2} \mathrm{~m}^{-2}$. The peak LAI for rainfed was about $4.3 \mathrm{~m}^{2} \mathrm{~m}^{-2}$. For irrigated soybean, the peak LAI was between 4.4 and $5.7 \mathrm{~m}^{2} \mathrm{~m}^{-2}$. Rainfed soybean had peak LAI between 3.1 and $4.4 \mathrm{~m}^{2} \mathrm{~m}^{-2}$.

\subsection{Growing season evapotranspiration}

\subsubsection{ET totals}

Measured evapotranspiration, integrated over the growing season during the 5 years of our study, is given in Figure $3 \mathrm{~A}$. For irrigated maize (ICM and IMS), the average growing season ET total was $548 \mathrm{~mm}$ (range: 502-586 mm). For rainfed maize, the average growing season ET was $482 \mathrm{~mm}$ (range: 449-505 mm). For irrigated and rainfed soybean (2 years of data in each case), the average ET values were $452 \mathrm{~mm}$ (range: $430-474 \mathrm{~mm}$ ) and $431 \mathrm{~mm}$ (range: 420-441
(A)

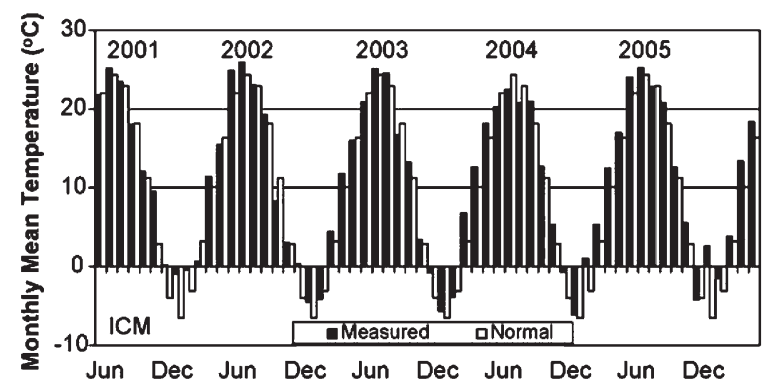

(B)

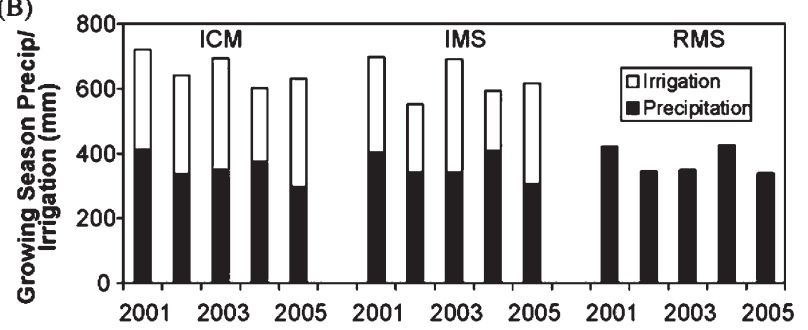

Figure 1. (A) Mean monthly air temperatures (measured at the irrigated continuous maize site, ICM) and 30-year climate normals (1971-2000 Climate Normals; HPRCC, 2006), (B) growing season precipitation and irrigation at the three sites. ICM $=$ irrigated continuous maize; IMS = irrigated maize-soybean rotation; RMS = rainfed maize-soybean rotation .

$\mathrm{mm})$, respectively. On average, the maize ET was higher than the soybean ET by $96 \mathrm{~mm}(18 \%)$ for irrigated crops and by $52 \mathrm{~mm}(11 \%)$ for rainfed crops (Figure 3B). The ET from irrigated maize was higher than that of the rainfed maize by $66 \mathrm{~mm}(12 \%)$. The ET for irrigated soybean was higher by $21 \mathrm{~mm} \mathrm{(5 \% )}$ as compared to the rainfed soybean. Variability in growing season ET totals is influenced by several atmospheric and biological factors. For example, $R_{\mathrm{n}}$ explained

Table 2. Growing season (GS: planting to harvest) and annual (Ann: planting to planting) totals of net radiation $\left(R_{\mathrm{n}}\right)$, evapotranspiration (ET), and combined precipitation and irrigation (Precip + Irrig) for all sites and years. Also included are the values of annual ET as a percentage of Precip + Irrig, annual ET as a percentage of net radiation, and growing season potential evapotranspiration $\left(\mathrm{ET}_{0}\right)$. In 2001 , values of $R_{n^{\prime}}$ ET, and precipitation were estimated during the period between planting and the initiation of measurements using data from a nearby weather station.

\begin{tabular}{|c|c|c|c|c|c|c|c|c|c|c|c|}
\hline \multirow[t]{2}{*}{ Year } & \multirow{2}{*}{$\begin{array}{l}\text { Site, crop } \\
\text { (M - maize; } \\
\text { S - soybean) }\end{array}$} & \multicolumn{2}{|c|}{$R_{\mathrm{n}}$} & \multicolumn{3}{|c|}{ ET } & \multicolumn{2}{|c|}{ Precip + Irrig } & \multirow{2}{*}{$\begin{array}{r}\text { ET } \\
\text { as } \% \\
\text { of } R_{n} \\
\text { Ann }(\%)\end{array}$} & \multirow{2}{*}{$\begin{array}{l}\text { ET as \% of } \\
\text { Precip + } \\
\text { Irrig } \\
\text { Ann (\%) }\end{array}$} & \multirow{2}{*}{$\begin{array}{r}\mathrm{ET}_{0} \\
\mathrm{GS} \\
(\mathrm{mm})\end{array}$} \\
\hline & & $\begin{array}{c}\text { GS } \\
(\mathrm{MJ})\end{array}$ & $\begin{array}{l}\text { Ann } \\
(\mathrm{MJ})\end{array}$ & $\begin{array}{c}\text { GS } \\
(\mathrm{mm})\end{array}$ & $\begin{array}{l}\text { Ann } \\
(\mathrm{mm})\end{array}$ & $\begin{array}{l}\text { Ann } \\
(\mathrm{MJ})\end{array}$ & $\begin{array}{c}\mathrm{GS} \\
(\mathrm{mm})\end{array}$ & $\begin{array}{c}\text { Ann } \\
(\mathrm{mm})\end{array}$ & & & \\
\hline 2001-2002 & ICM, M & 2005 & 2738 & 586 & 714 & 1714 & 525 & 684 & 63 & 104 & 681 \\
\hline 2002-2003 & ICM, M & 2078 & 2828 & 565 & 679 & 1661 & 644 & 840 & 59 & 81 & 777 \\
\hline 2003-2004 & ICM, M & 1948 & 2532 & 540 & 640 & 1567 & 558 & 733 & 62 & 87 & 676 \\
\hline 2004-2005 & ICM, M & 1923 & 2645 & 502 & 618 & 1514 & 523 & 682 & 57 & 91 & 652 \\
\hline 2005-2006 & ICM, M & 1994 & 2776 & 526 & 687 & 1682 & 593 & 813 & 61 & 85 & 791 \\
\hline 2001-2002 & IMS, M & 1996 & 2899 & 535 & 691 & 1663 & 597 & 798 & 57 & 87 & 685 \\
\hline 2002-2003 & IMS, S & 1802 & 2732 & 474 & 638 & 1561 & 576 & 795 & 57 & 80 & 687 \\
\hline 2003-2004 & IMS, M & 2008 & 3042 & 578 & 746 & 1825 & 636 & 934 & 60 & 80 & 675 \\
\hline 2004-2005 & IMS, S & 1548 & 2287 & 430 & 566 & 1388 & 443 & 707 & 61 & 80 & 527 \\
\hline 2005-2006 & IMS, M & 2077 & 2869 & 550 & 690 & 1689 & 629 & 912 & 59 & 76 & 785 \\
\hline 2001-2002 & RMS, M & 1894 & 2768 & 505 & 656 & 1582 & 318 & 512 & 57 & 128 & 686 \\
\hline 2002-2003 & RMS, S & 1725 & 2576 & 441 & 599 & 1466 & 373 & 601 & 57 & 100 & 692 \\
\hline 2003-2004 & RMS, M & 1845 & 2894 & 449 & 621 & 1520 & 290 & 622 & 53 & 100 & 654 \\
\hline 2004-2005 & RMS, S & 1461 & 2105 & 420 & 553 & 1357 & 311 & 575 & 64 & 96 & 511 \\
\hline 2005-2006 & RMS, M & 2014 & 2741 & 493 & 616 & 1506 & 364 & 653 & 55 & 94 & 777 \\
\hline
\end{tabular}



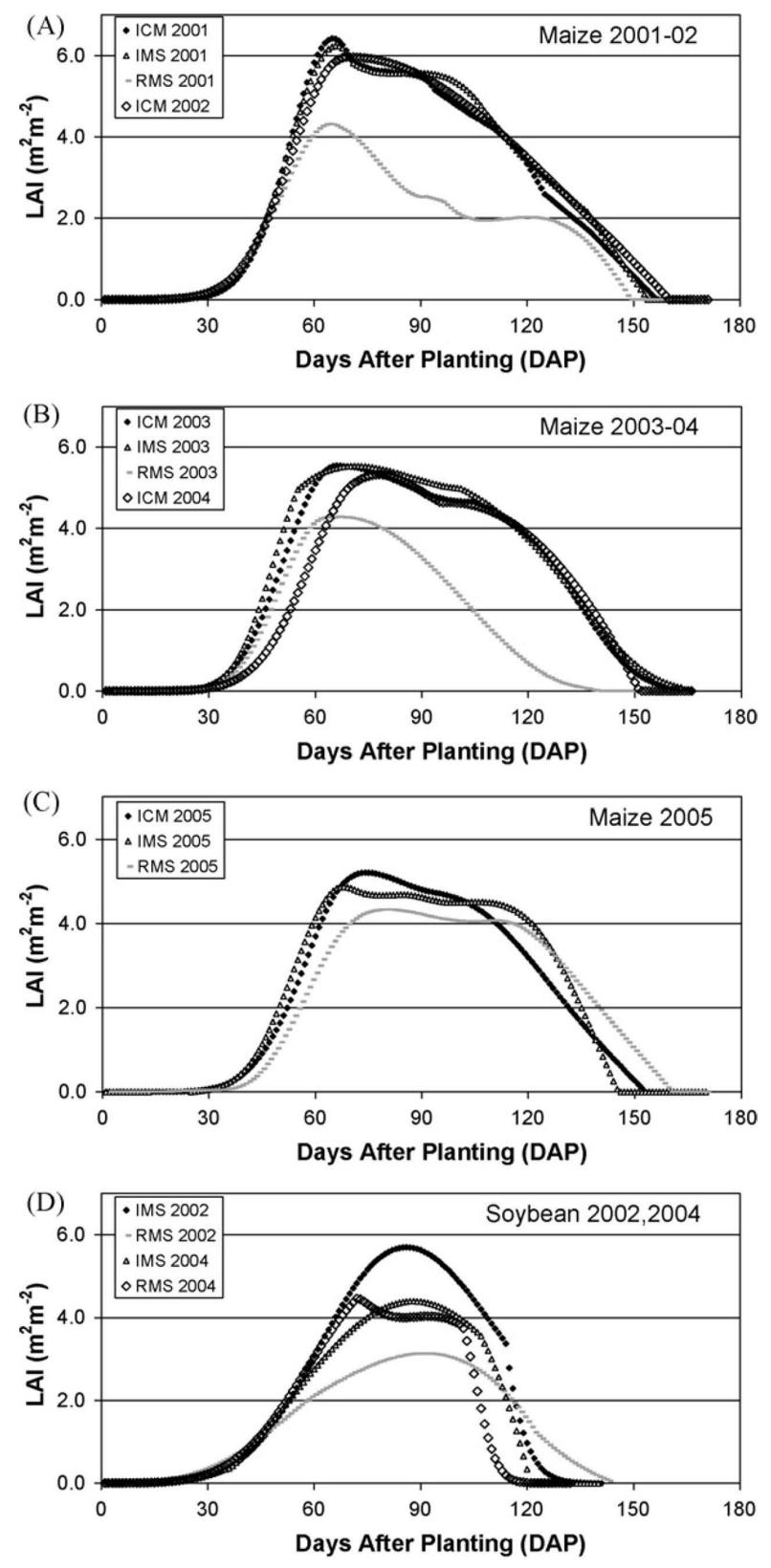

Figure 3. Growing season evapotranspiration (ET): (A) for each year and site, (B) average and range for each crop (irrigated and rainfed), and (C) growing season ET vs. the number of days with LAI $>2.5 \mathrm{~m}^{2} \mathrm{~m}^{-2}$. ICM = irrigated continuous maize; IMS = irrigated maize-soybean rotation; RMS = rainfed maize-soybean rotation. In (A), M = maize and $\mathrm{S}=$ soybean.

$75 \%$ of the variability in ET totals of both crops and all years studied. Similarly, leaf area plays an important role (e.g., Suyker and Verma, 2008). About $66 \%$ of the variability in the growing season ET total was explained by the number of days when the LAI was greater than $2.5 \mathrm{~m}^{2} \mathrm{~m}^{-2}$ (Figure 3C).

These growing season ET totals are generally comparable to results from other studies in the region. For example, from their 2 years of study in central Kansas, Hattendorf et al. (1988) reported the average ET of irrigated and rainfed maize of 568 and $561 \mathrm{~mm}$, respectively. Schneekloth et al. (1991) reported a 3-year average maize ET of 640,557, and $389 \mathrm{~mm}$
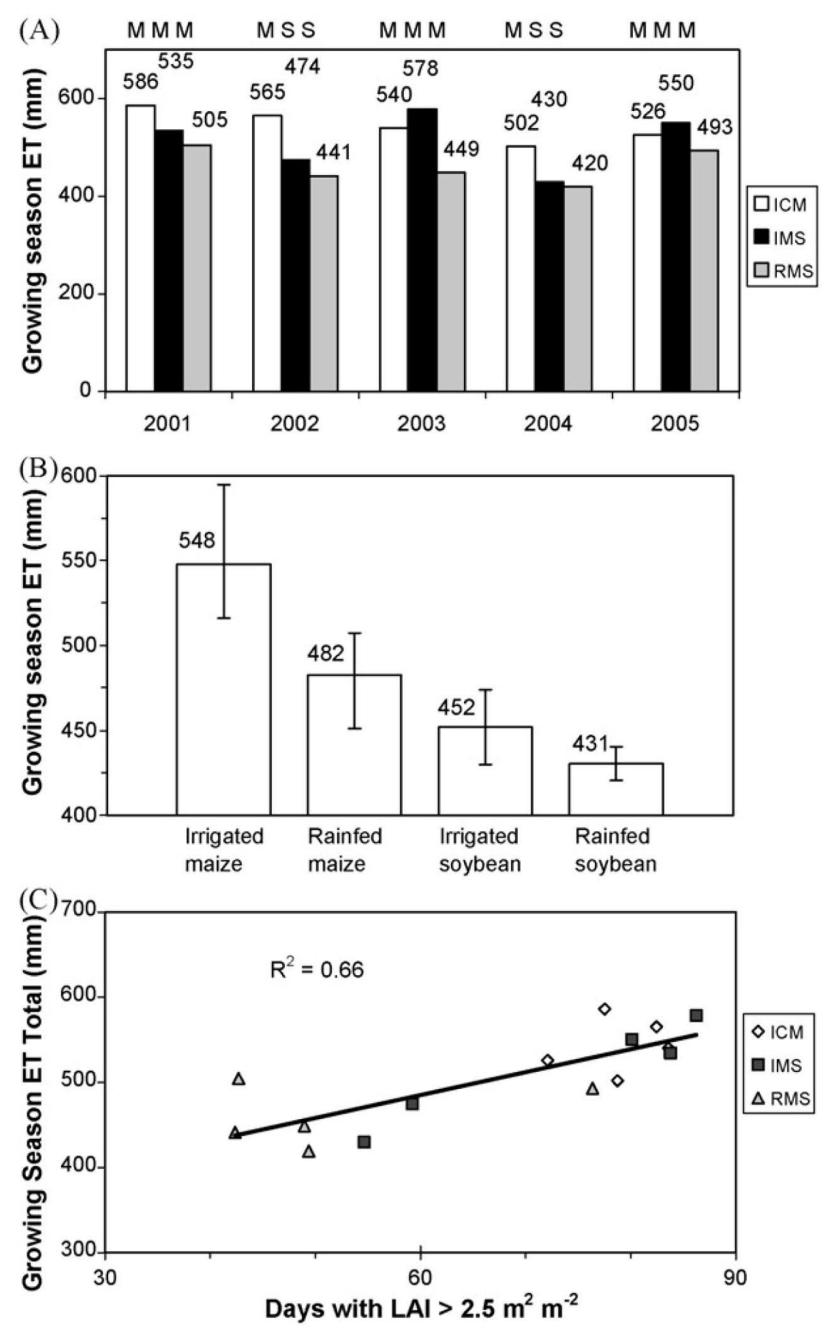

Figure 2. Green leaf area (LAI) at the three sites for (A) maize canopies in 2001 and 2002, (B) maize canopies in 2003 and 2004, (C) maize canopies in 2005, and (D) soybean canopies in 2002 and 2004. ICM = irrigated continuous maize; IMS = irrigated maizesoybean rotation; RMS = rainfed maize-soybean rotation.

for full, limited, and rainfed conditions in west central Nebraska. For soybean, average growing season ET in the three irrigation regimes was 520,520, and $426 \mathrm{~mm}$. In northwest Kansas, Lamm et al. (1995) measured a 3-year average maize ET of 586, 542, and $459 \mathrm{~mm}$ under full, half and no irrigation. In southwest Kansas, Norwood (1999) measured ET from 395 to $601 \mathrm{~mm}$ for rainfed maize in no-till management and 385-505 $\mathrm{mm}$ in conventional tillage over four growing seasons. For rainfed soybean, he reported ET ranging from 450 to 470 and from 408 to $476 \mathrm{~mm}$, respectively for the two management practices.

\subsubsection{Seasonal distributions of ET/ET}

Seasonal distributions of daily ET, normalized by the reference evapotranspiration $\left(\mathrm{ET}_{0}\right.$, calculated using the $\mathrm{FAO}$ Penman-Monteith equation: Allen et al., 1998), are given in Figure 5 and Figure 6 . Normalizing ET by $\mathrm{ET}_{0}$ is intended to account for the day-to-day variability in atmospheric conditions (also, the seasonal totals of $\mathrm{ET}_{0}$ are given in Table 2). 

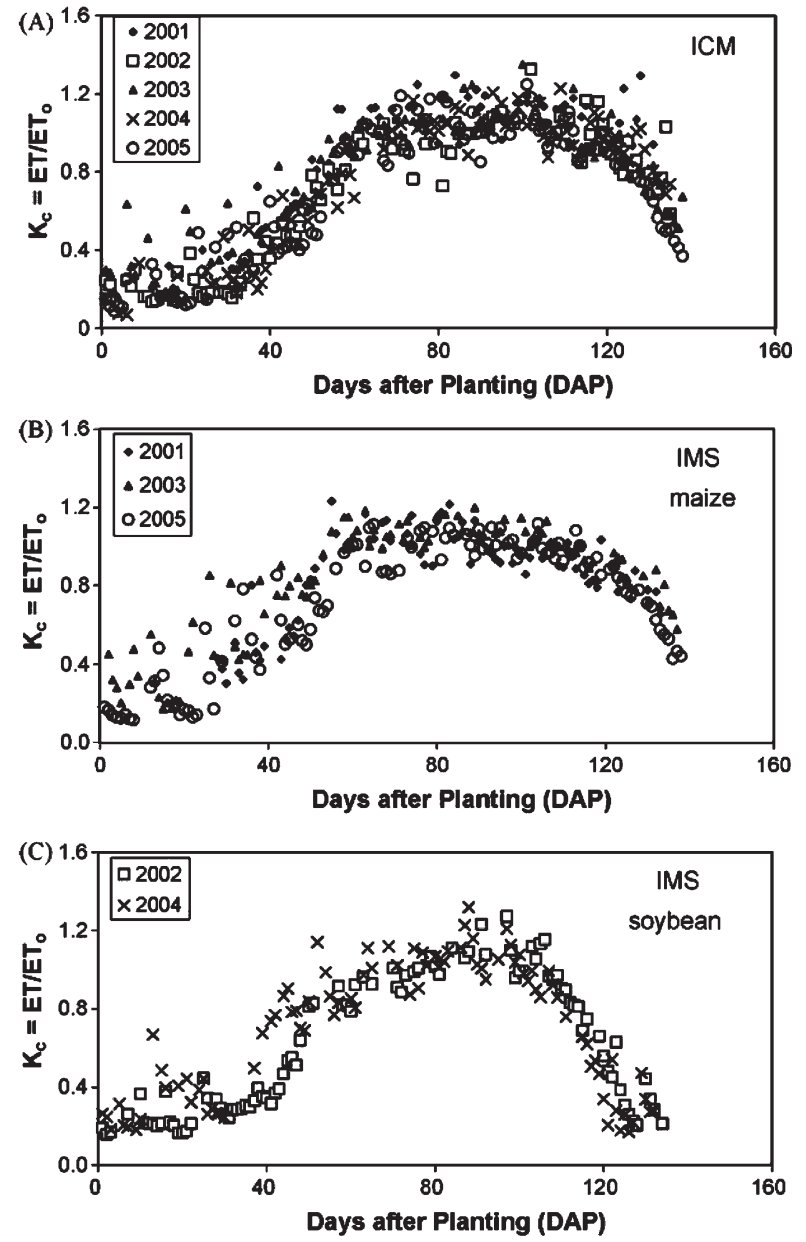

Figure 4. Seasonal distributions of crop coefficient $K_{c}=\mathrm{ET} / \mathrm{ET}_{0}$ at the irrigated sites: (A) irrigated maize over 5 years at ICM, (B) irrigated maize for 3 years at IMS, and (C) irrigated soybean over 2 years at IMS. Days with precipitation have been removed. ICM = irrigated continuous maize; IMS = irrigated maize-soybean rotation; RMS = rainfed maize-soybean rotation .

The $\mathrm{ET} / \mathrm{ET}_{0}$ ratio is also commonly referred to as the crop coefficient ( $K_{c^{\prime}}$ e.g., Allen et al., 1998). For irrigated maize in both ICM and IMS fields, prior to emergence (LAI < 0.5), $K_{c}$ was $0.27 \pm 0.17$ (95\% confidence interval; Figure $4 \mathrm{~A}$ and B; Table 3). During this period, evaporation from soil/residue is important and the variability in the magnitude of $K_{c}$ is primarily affected by surface conditions (e.g., mulch cover, rain, heavy dew). With increasing LAI, $K_{c}$ increased reaching a mid-season average of $1.03 \pm 0.07$ (Table 3). By the end of the growing season $(\mathrm{DAP}=135-140), K_{\mathrm{c}}$ was $0.33 \pm 0.17$. The seasonal distribution of $K_{c}$ in the irrigated maize fields appears to be quite consistent among the years. Also, our $K_{c}$ values are generally within the range of the values recommended in the Food and Agricultural Organization of the United Nations (FAO) report (Table 3; Allen et al., 1998) for our region: 0.3 (initial part of the season), $1.16 \pm 0.04$ (midseason, adjusted for climatic conditions at our sites based on their recommendations), and 0.35 (end of season).

The seasonal distribution of $K_{c}$ in the irrigated soybean was also quite consistent between the two growing seasons
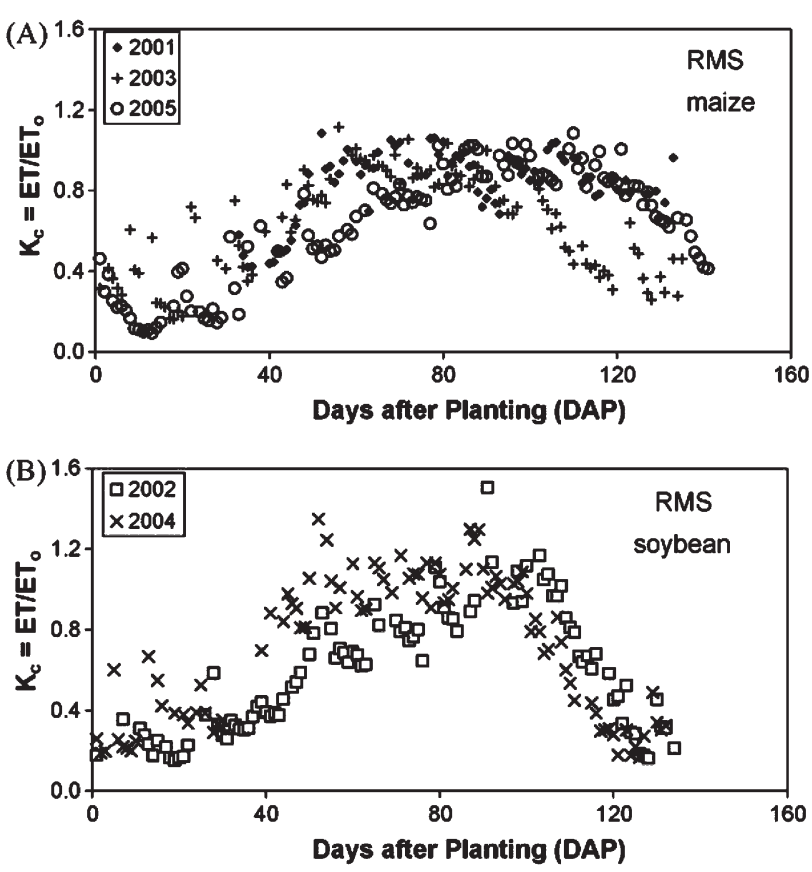

Figure 5. Seasonal distributions of crop coefficient $K_{c}=E T / E_{0}$ in rainfed sites: (A) maize over 3 years at RMS, and (B) soybean for 2 years at RMS. Days with precipitation have been removed. RMS = rainfed maize-soybean rotation .

(Figure 4C) even though the 2004 crop was a different hybrid, was planted later, and had lower LAI (Table 1; Figure 2). Before significant leaf emergence, $K_{c}$ values were about the same as those in irrigated maize $(0.27 \pm 0.17)$. Then, in 2 weeks (DAP $=41-55), K_{c}$ increased somewhat rapidly from about 0.3 to 0.9 . Further increase in $K_{\mathrm{c}}$ was gradual, reaching a mid-season value of $0.98 \pm 0.02$. In comparison to maize, the duration of mid-season plateau in $K_{c}$ is shorter by about 30 days. With senescence, there was a rapid decrease in $K_{c}$ over a period of about 3 weeks. At the end of the growing season, $K_{c}$ was $0.32 \pm 0.12$. These results are also generally within range of the values recommended in the FAO report for our region (Allen et al., 1998): 0.4 (initial part of the season), $1.14 \pm 0.03$ (mid-season, adjusted for climatic conditions at our sites), and 0.5 (end of season).

As expected, there was significantly larger year-to-year variability in the seasonal distributions of $K_{c}$ for the rainfed crops (Figure 5). In Figure 6, these results are examined against the corresponding values for the irrigated crops in conjunction with the precipitation distributions. Dry-down periods (periods with extended gaps without any significant precipitation: $>5 \mathrm{~mm} /$ event) occurred during different parts of the season in 2001, 2003, and 2005. Towards the end of dry-down periods (e.g., 70-93 DAP in 2001, 67-97 DAP in 2003, and 54-83 DAP in 2005), $K_{c}$ tended to decrease below the corresponding value for the irrigated crop. Rise in $K_{c}$ was observed following a significant rain (>20 mm/event). Average mid-season $K_{c}$ of rainfed maize was $0.84 \pm 0.20$ over the 3 years of our measurements (Table 3 ). In soybean years, there seemed to be sufficient rainfall events throughout the growing season in 2004 and during mid- to late season in 2002. Dry-down early in the 2002 season helped temporarily 
lower the rainfed $K_{c}$ values. Without significant mid-season dry-down in rainfed soybean, mid-season $K_{c}(0.90 \pm 0.13$; Table 3) was only slightly lower than those for irrigated fields $(0.98 \pm 0.02)$.

\subsection{Non-growing season evaporation}

For the non-growing season periods (harvest to subsequent planting), evaporation totals (E) ranged from 100 to $172 \mathrm{~mm}$ during the 5 years of our study (Figure 7A). Combining these values with the growing season ET, the average annual ET (from planting to planting) for irrigated maize was $683 \mathrm{~mm}$ (668 $\mathrm{mm}$ for ICM, $709 \mathrm{~mm}$ for IMS). The average annual ET for rainfed maize was $631 \mathrm{~mm}$. For soybean, annual ET averaged 602 and $576 \mathrm{~mm}$ for irrigated and rainfed conditions, respectively. The non-growing season $E$ total, as a percentage of annual ET, was 16-28\% in irrigated/rainfed maize (16-23\% in ICM, 20-23\% in IMS, and 20-28\% in RMS) and 24-26\% in irrigated/rainfed soybean. On an annual basis (Table 2), ET accounted for about $53-64 \%$ of annual $R_{n}$ at our study sites. In terms of the water input, the annual ET was generally $76-91 \%$ of precipitation + irrigation at the irrigated sites and about 94$100 \%$ of precipitation at the rainfed site.

Since soybeans are generally planted later and harvested earlier than maize, to facilitate a more accurate examination of interannual variability, we integrated evaporation over a common period: 1 November-1 May. The total evaporation over this common period ranged from 94 to $143 \mathrm{~mm}$ (Figure 7B). Some features of the non-growing season $E$ become readily apparent (Figure $7 \mathrm{~B}$ ). The maize-soybean rotation had very similar non-growing season $E$ through all 5 years, regardless of irrigation. Also, the non-growing season $E$ in continuous maize during the first 4 years (2001-2002 to 2004-2005) was consistently lower than that from the maizesoybean rotations (average $E$ in ICM was $100 \mathrm{~mm}$ compared to $116 \mathrm{~mm}$ in IMS and RMS). In contrast, following the 2005 conservation plowing, the non-growing season $E$ was the highest measured over 5 years $(143 \mathrm{~mm})$. The interannual variability in non-growing season $E$ seems reasonable considering the different amounts of mulch left after harvest.

In Figure 8, we examine the non-growing season $E / E_{\mathrm{eq}}$ (where $E_{\mathrm{eq}}$ is the equilibrium evaporation-e.g., Slatyer and McIlroy, 1961) as a function of mulch biomass left after harvest (Table 1 ). Here $E$ has been normalized by $E_{\text {eq }}$ to help account for the variability in relevant atmospheric conditions. As seen in Figure 8, the amount of surface mulch biomass seemed to explain $71 \%$ of the interannual variability in nongrowing season E. Considering that these measurements covered a wide range of mulch biomass in both no-till and conservation-plowed maize-soybean systems, results in Figure 8 indicated a dominant role of mulch biomass in controlling non-growing season evaporation.

\subsection{Energy partitioning}

As noted in an earlier paper (Suyker and Verma, 2008), in irrigated fields, the Bowen ratio $(\beta)$ was comparable ranging from 0.3 to -0.3 for maize and soybean when the canopy was fully developed (negative values are associated with conditions of sensible heat advection - see Rosenberg et al., 1983 for a discussion of the phenomenon). Here we compare $\beta$ (midday average from 1200 to $1400 \mathrm{~h}$, local time) for irrigated and rainfed maize during the growing season (Figure 9A). With the onset of a dry period in August, $\beta$ in the rainfed maize field became larger ranging up to 1.8. Values of $\beta$ in both fields were large (2.0-4.0) during senescence in September. In the non-growing season (Figure 9B), $\beta$ varied widely. The value of $\beta$ was fairly large when the surface was dry and was near zero on cool/cloudy days with wet surface conditions.

Table 3. $K_{c}$ values and $95 \%$ confidence intervals for specified periods of the growing season (ICM=irrigated continuous maize; IMS = irrigated maize-soybean rotation; RMS = rainfed maize-soybean rotation). Integration periods for initial, middle and end of the growing season were related to crop growth stages as recommended by Allen et al. (1998). The mid-season $K_{c}$ FAO-56 is from the FAO report (Allen et al., 1998) adjusted for climatic conditions and canopy height. Measurements at the RMS began after the initial growth period in 2001, so the initial $K_{c}$ is missing.

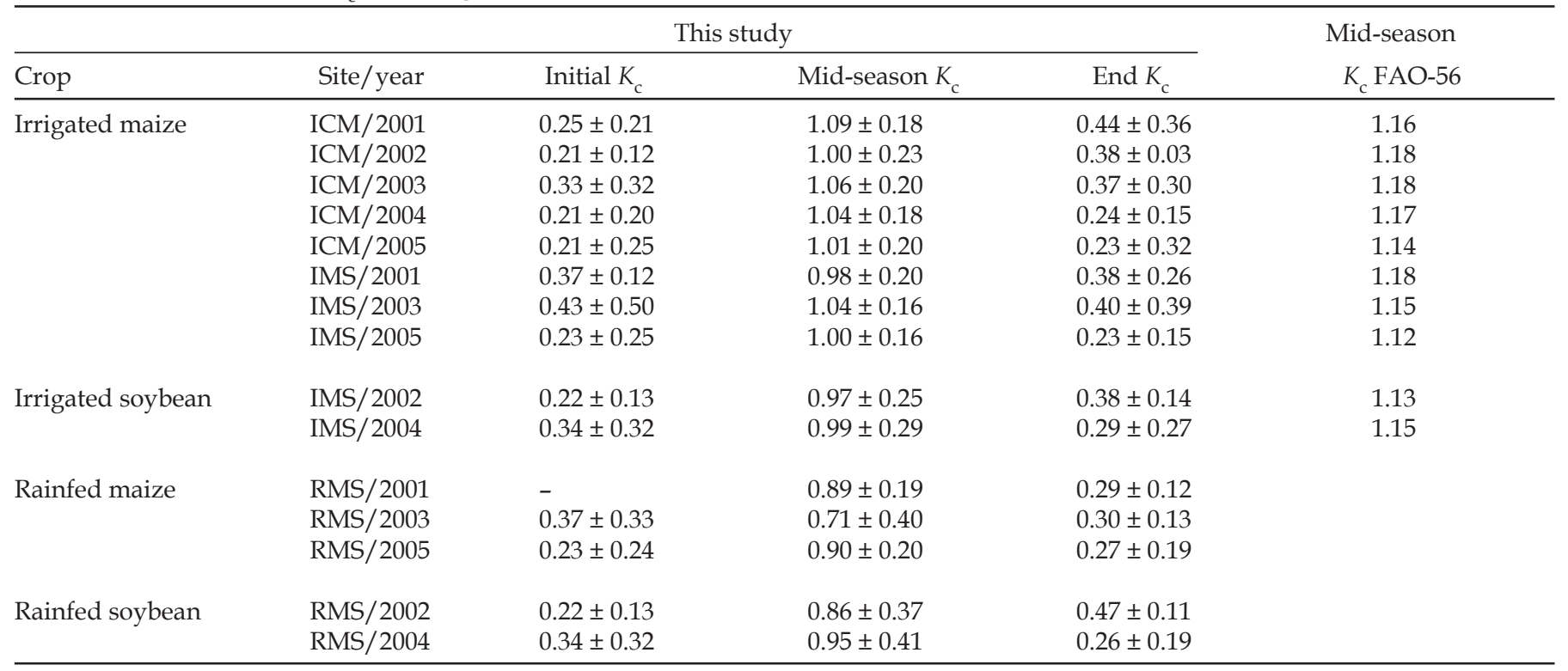



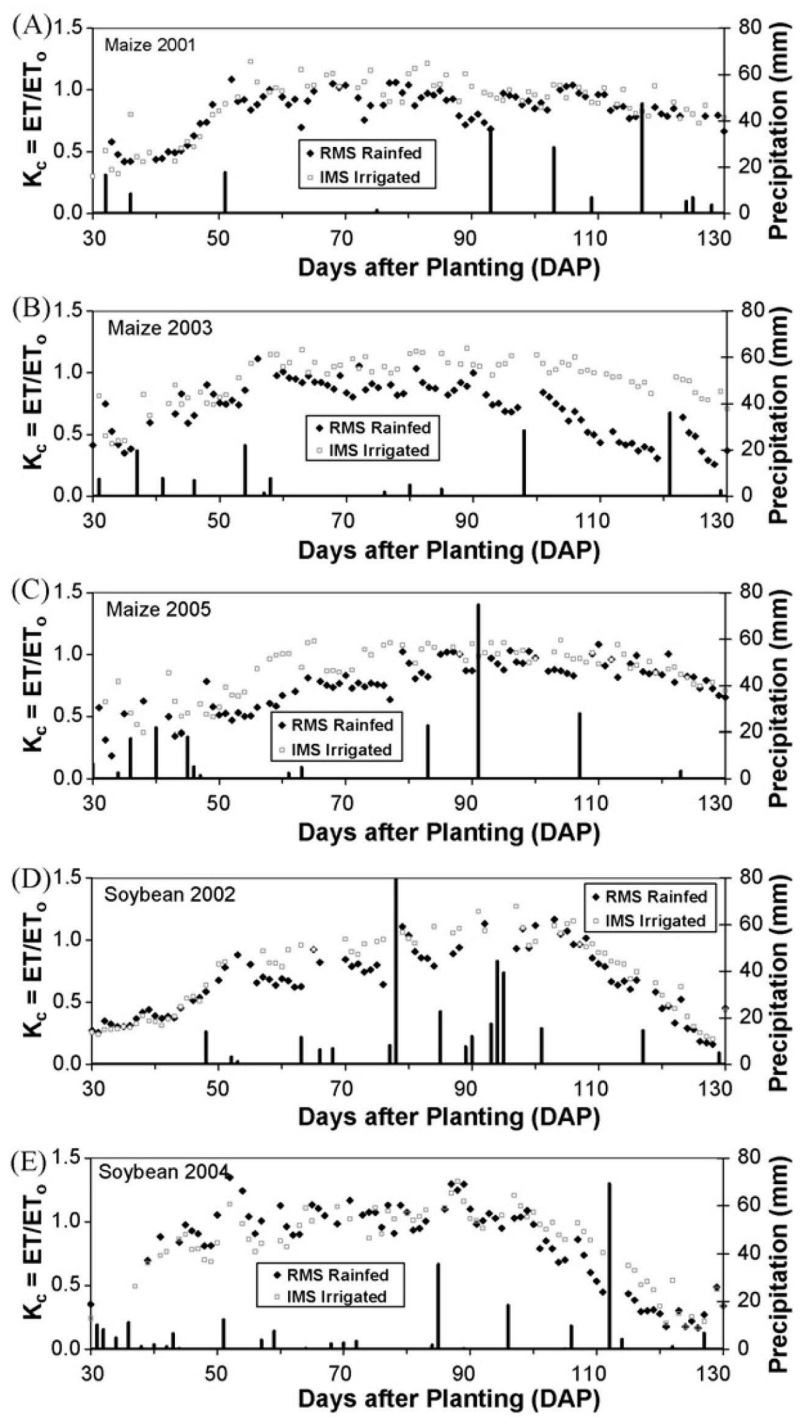

Figure 6. Seasonal distributions of crop coefficient $K_{\mathrm{c}}=\mathrm{ET} / \mathrm{ET}_{0}$ and precipitation at the rainfed site (RMS) in (A) 2001, (B) 2003, (C) 2005, (D) 2002, and (E) 2004. The $K_{c}$ for the corresponding irrigated crop (IMS) is also included for comparison. IMS = irrigated maize-soybean rotation; RMS = rainfed maize-soybean rotation .

\subsection{Water use efficiency (WUE)}

Here we present our results using two commonly used definitions of water use efficiency (WUE). First, WUE $\mathrm{ET}_{\mathrm{ET}}$ or ET efficiency, defined as the ratio of grain yield $(Y)$ to growing season evapotranspiration (ET), is plotted for all three sites in Figure 10A. For irrigated maize, the average value was $2.00 \pm 0.15 \mathrm{~g} \mathrm{~kg}^{-1}$ (95\% confidence interval) with little interannual variation. In the rainfed maize, average values were about $25 \%$ smaller $\left(1.49 \pm 0.12 \mathrm{~g} \mathrm{~kg}^{-1}\right)$, but as steady as the irrigated maize. Our results on $\mathrm{WUE}_{\mathrm{ET}}$ are bracketed by the range of values observed in several studies on maize (generally $1.6 \mathrm{~g} \mathrm{~kg}^{-1}$ in arid regions and $2.7 \mathrm{~g} \mathrm{~kg}^{-1}$ in humid regions: Tanner and Sinclair, 1983). For soybean, our data indicated no significant difference between irrigated and rainfed WUE $E_{\mathrm{ET}}$ with average values of $0.71 \pm 0.03$ and $0.68 \pm 0.07 \mathrm{~g} \mathrm{~kg}^{-1}$, respectively.
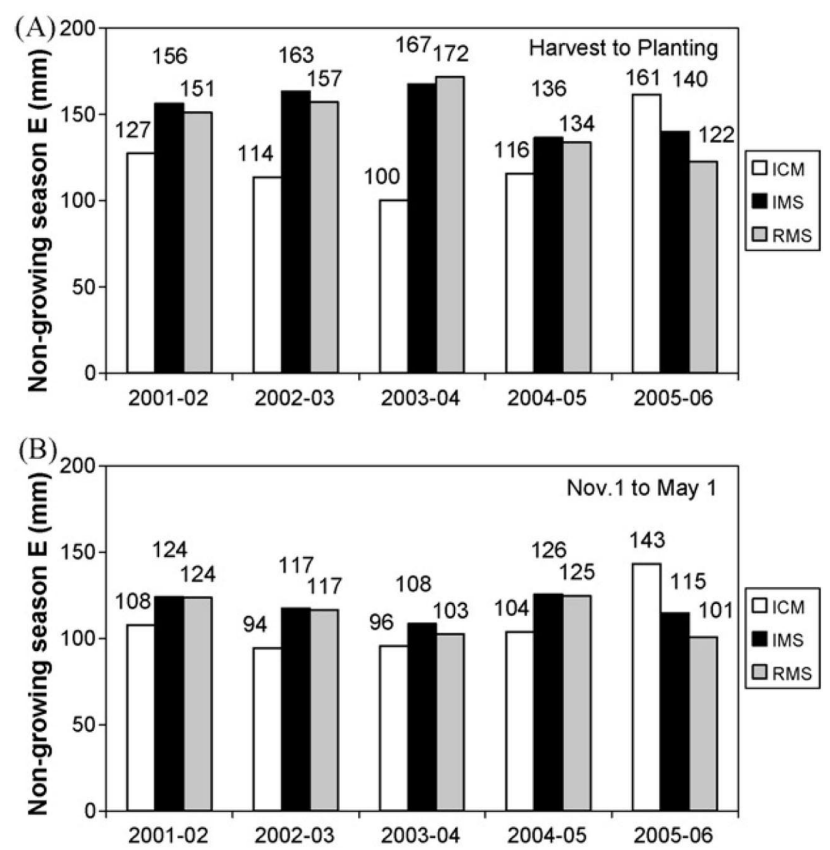

Figure 7. Integrated evaporation $(E)$ during the non-growing season periods for each of the 5 years at all three sites during (A) harvest to planting and (B) the common integration period from 1 November to 1 May. ICM = irrigated continuous maize; IMS = irrigated maize-soybean rotation; RMS = rainfed maize-soybean rotation.

Water use efficiency, WUE $\mathrm{DM}_{\mathrm{DM}}$ or biomass transpiration efficiency, is defined as the ratio of total plant biomass $\left(Y_{\mathrm{DM}}\right.$ : above plus below ground) to growing season transpiration (T). Following Amos and Walters (2006), we assumed an 11\% root to shoot ratio for maize and $20 \%$ for soybean at physiological maturity. We estimated soil evaporation $(E)$ from measured atmospheric and biophysical variables following Ritchie (1972) and Tanner and Jury (1976). The WUE ${ }_{D M}$ values (Figure 10B) show virtually the same average for irrigated and rainfed maize with small interannual variability, $5.20 \pm 0.34$ and $5.22 \pm 0.36 \mathrm{~g} \mathrm{~kg}^{-1}$, respectively. For soybean, $W U E_{\mathrm{DM}}$ for irrigated and rainfed sites is $3.21 \pm 0.35$ and $2.96 \pm 0.30 \mathrm{~g} \mathrm{~kg}^{-1}$, respectively. For these two crops, there was no significant difference between the WUE $\mathrm{DM}_{\mathrm{M}}$ in irrigated and rainfed systems.

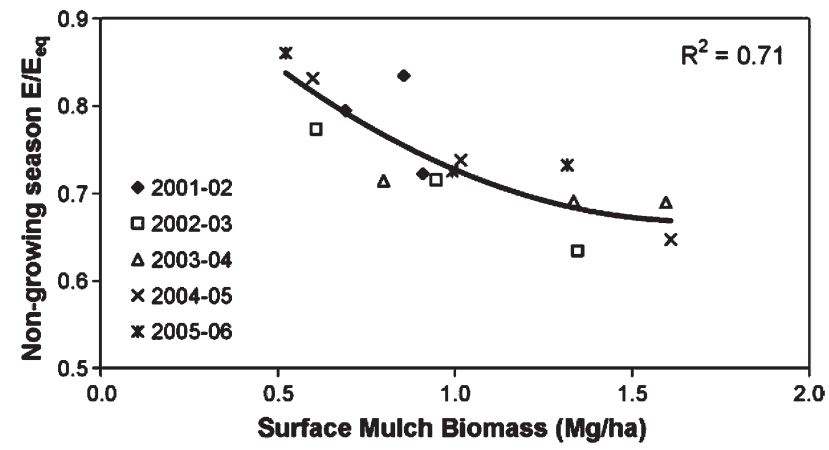

Figure 8. Non-growing season evaporation ( $E$ : integrated from 1 November to 1 May) normalized by equilibrium evaporation $\left(E_{\mathrm{eq}}\right)$ as a function of seasonal average surface mulch biomass. 

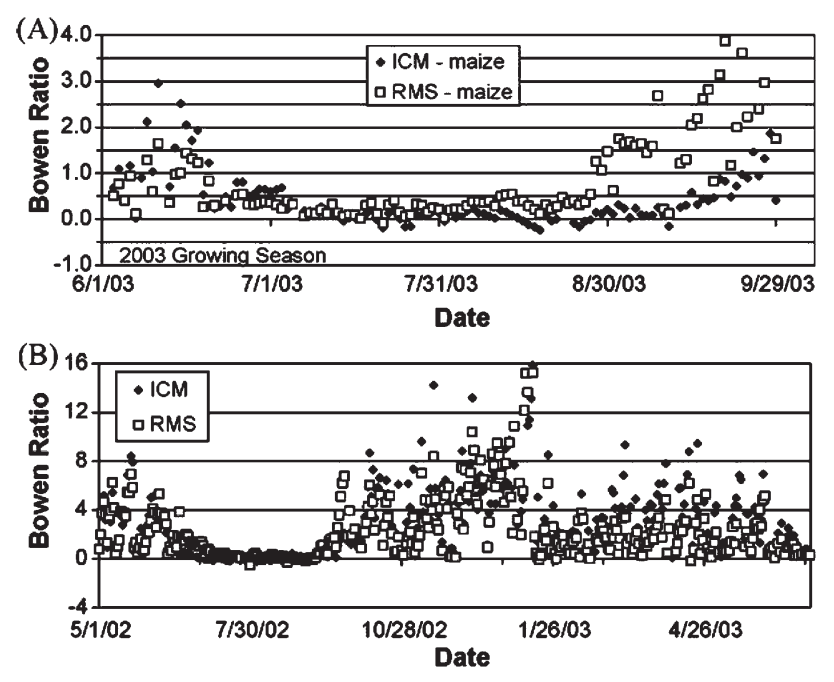

Figure 9. Midday averaged (1200-1400 h, local time) Bowen ratio for irrigated continuous maize (ICM) and rainfed maize soybean (RMS) during (A) the 2003 growing season (maize in both fields) and (B) the 2002 growing season (maize in ICM and soybean in RMS) and the subsequent non-growing season period. Data during precipitation were not included.

\section{Summary and conclusions}

Evapotranspiration (ET) was measured in three fields of irrigated continuous maize, irrigated maize-soybean rotation, and a rainfed maize-soybean rotation at Mead, NE during 2001-2005. For irrigated and rainfed maize, growing season ET ranged from 502 to 586 and 449 to $505 \mathrm{~mm}$, respectively. For irrigated and rainfed soybean, ET ranged from 430 to 474 and 420 to $441 \mathrm{~mm}$, respectively. The ET for
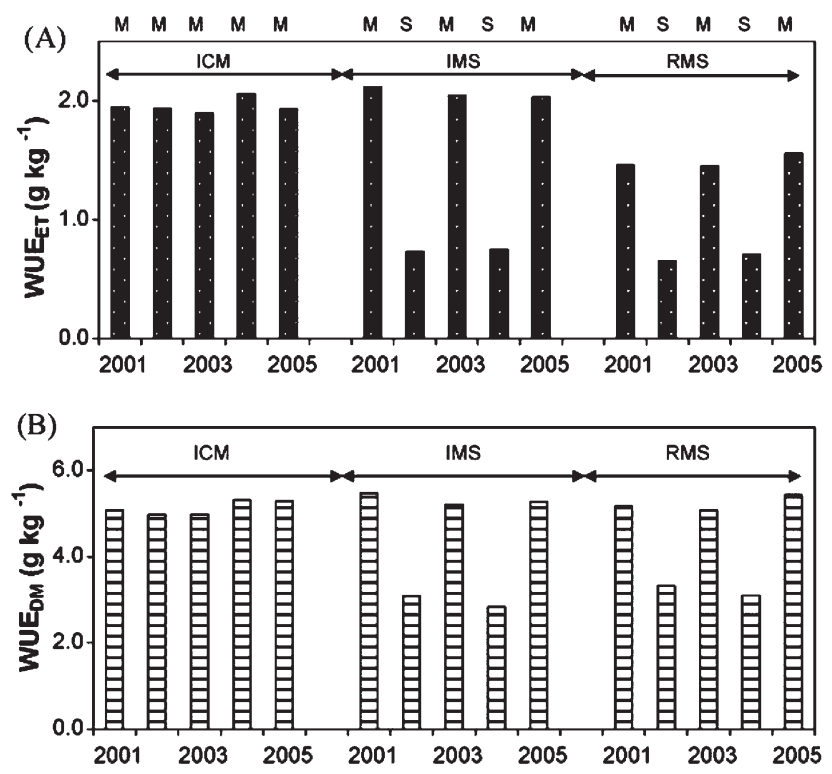

Figure 10. Water use efficiency calculated for each site/year defined as (A) the ratio of grain yield to growing season evapotranspiration $\left(\mathrm{WUE}_{\mathrm{ET}}\right)$, and $(\mathrm{B})$ the ratio of total plant biomass to growing season transpiration $\left(\mathrm{WUE}_{\mathrm{DM}}\right)$. ICM = irrigated continuous maize; IMS = irrigated maize-soybean rotation; $\mathrm{RMS}=$ rainfed maize-soybean rotation. In (A), $\mathrm{M}=$ maize and $\mathrm{S}=$ soybean. irrigated maize was higher than rainfed maize by $12 \%$ and the ET for irrigated soybean was higher than rainfed soybean by $5 \%$. During the growing season, the crop coefficient $\left(K_{c}\right)$ for irrigated maize was approximately $0.27 \pm 0.17$ early in the season, $1.03 \pm 0.07$ during mid-season, and $0.33 \pm 0.17$ at the end of the season. Similarly, the corresponding $K_{\mathrm{c}}$ for irrigated soybean was $0.27 \pm 0.17,0.98 \pm 0.02$, and $0.32 \pm 0.12$, respectively. Annual ET (planting to planting) averaged 683 and $631 \mathrm{~mm}$ for irrigated and rainfed maize, respectively. For soybean, average annual ET was 602 and $576 \mathrm{~mm}$ for irrigated and rainfed conditions, respectively. Non-growing season evaporation contributed $16-28 \%$ of annual ET totals in irrigated and rainfed maize and $24-26 \%$ in irrigated and rainfed soybean. Water use efficiency (evapotranspiration efficiency), based on the ratio of yield to growing season ET, was $2.00 \mathrm{~g} \mathrm{~kg}^{-1}$ in irrigated maize and about $25 \%$ lower in rainfed maize. The WUE in irrigated and rainfed soybean was comparable (0.71 and $0.68 \mathrm{~g} \mathrm{~kg}^{-1}$, respectively).

\section{Acknowledgments}

The research discussed here was supported by the Office of Science (BER), U.S. Department of Energy Grant no. DE-FG0203ER63639 and the University of Nebraska-Lincoln Program of Excellence. We gratefully acknowledge the technical assistance of Ed Cunningham, Todd Schimelfenig, Jim Hines, and Mark Schroeder. We thank Dr. Tim Arkebauer and Dave Scoby for providing data on leaf area. We thank Dr. Derrel Martin, Dr. Suat Irmak and Mr. Luis Octavio Lagos for their valuable assistance calculating reference ET.

\section{References}

Allen et al., $1998 \rightarrow$ R. G. Allen, L. S. Pereira, D. Raes, and M. Smith, 1998. Crop evapotranspiration. Guidelines for Computing Crop Water Requirements. FAO Irrig. and Drain. Paper 56. FAO, Rome.

Amos and Walters, 2006 B. Amos and D. T. Walters, Maize root biomass and net rhizodeposited carbon: an analysis of the literature, Soil Sci. Soc. Am. J. 70 (2006), pp. 1489-1503.

Baldocchi et al., $1988 \rightarrow$ D. D. Baldocchi, B. B. Hicks, and T. P. Meyers, Measuring biosphere-atmosphere exchanges of biologically related gases with micrometeorological methods, Ecology 69 (5) (1988), pp. 1331-1340.

Baldocchi et al., 1997 D. D. Baldocchi, C. Vogel and B. Hall, Seasonal variation of carbon dioxide exchange rates above and below a boreal Jack pine forest, Agric. For. Meteorol. 83 (1997), pp. 147-170.

Bockus and Shroyer, $1998 \longrightarrow$ W. W. Bockus and J. P. Shroyer, 1998. The impact of reduced tillage on soilborne plant pathogens. Annu. Rev. Phytopathol. 36, 485-500, doi:10. 1146/annurev. phyto. 36. 1. 485.

Bowman and Collins, 1987 J. A. Bowman and M. A. Collins, 1987. Impacts of Irrigation and Drought on Illinois Ground-Water Resources. Report of Investigation, Illinois State Water Survey, Champaign.

Boyer, 1982 J. S. Boyer, Plant productivity and environment, Science 218 (4571) (1982), pp. 443-448.

Denmead and Shaw, 1960 O. T. Denmead and R. H. Shaw, The effects of soil moisture stress at different stages of growth on the development and yield of corn, Agron. J. 52 (1960), pp. 272-274. 
Easterling and Karl, $2001 \rightarrow$ D. R. Easterling and T. R. Karl, Potential consequences of climate variability and change for the Midwestern United States, Climate Change Impacts on the United States: The Potential Consequences of Climate Variability and Change, National Assessment Synthesis Team, Report for the US Global Change Research Program, Cambridge University Press, Cambridge, UK (2001) pp. 167-188.

Farahani et al., $2007 \rightarrow$ H. J. Farahani, T. A. Howell, W. J. Shuttleworth and W. C. Bausch, Evapotranspiration: progress in measurement and modeling in agriculture, Trans. ASABE 50 (5) (2007), pp. 1627-1638.

Graham et al., 2007 R. L. Graham, R. Nelson, J. Sheehan, R. D. Perlack, and L. L. Wright, 2007. Current and Potential U. S. Corn Stover Supplies. Agron. J. 99, 1-11, doi:10. 2134/ agronj2005. 0222.

Hatfield et al., 2001 J. L. Hatfield, T. J. Sauer, and J. H. Prueger, Managing soils to achieve greater water use efficiency: a review, Agron. J. 93 (2001), pp. 271-280.

Hattendorf et al., 1988 M. J. Hattendorf, M. S. Dedelfs, B. Amos, L. R. Stone, and R. E. Given Jr., Comparative water use characteristics of six row crops, Agron. J. 80 (1988), pp. 80-85.

HPRCC, 2006 High Plains Regional Climate Center, 2006. Mead, NE. 1971-2000 Climate Normals. Retrieved December 2000, from ACIS database.

Ji and Unger, $2001>$ S. Ji and P. W. Unger, Soil water accumulation under different precipitation, potential evaporation, and straw mulch conditions, Agron. J. 65 (2001), pp. 442-448.

Kim et al., 1992 J. Kim, S. B. Verma, and R. J. Clement, Carbon dioxide budget in a temperate grassland ecosystem, J. Geophys. Res. 97(D5) (1992), pp. 6057-6063.

Kucharik and Twine, 2007 C. J. Kucharik and T. E. Twine, Residue, respiration, and residuals: evaluation of a dynamic agroecosystem model using eddy flux measurements and biometric data, Agric. For. Meteorol. 146 (2007), pp. 134-158.

Kochsiek et al., in submission A. E. Kochsiek, J. M. H. Knops, D. T. Walters, and T. J. Arkebauer. Impacts of management on decomposition and the litter carbon balance in irrigated and rainfed no-till agricultural systems. In submission to Agric. For. Meteorol.

Lamm et al., 1995 F. R. Lamm, H. L. Manges, L. R. Stone, A. H. Khan, and D. H. Rogers, Water requirement of subsurface drip-irrigated corn in northwest Kansas, Trans. ASAE 38 (2) (1995), pp. 441-448.

Massman, 1991 W. J. Massman, The attenuation of concentration fluctuations in turbulent flow in a tube, J. Geophys. Res. 96 (1991), pp. 15269-15273.

Moore, 1986 C. J. Moore, Frequency response correction for eddy correlation systems, Boundary-Layer Meteorol. 37 (1986), pp. 17-35.

Musick and Dusek, $1980 \rightarrow$ J. T. Musick and D. A. Dusek, Irrigated corn yield response to water, Trans. ASAE 23 (1980), pp. 92-98.

Meyers and Hollinger, 2004 T. P. Meyers and S. E. Hollinger, An assessment of storage terms in the surface energy balance of maize and soybean, Agric. For. Meteorol. 125 (2004), pp. 105-116.

Norwood, $1999 \rightarrow$ C. A. Norwood, Water use and yield of dryland row crops as affected by tillage, Agron. J. 91 (1999), pp. 108-115.

Ritchie, $1972 \downarrow$ J. T. Ritchie, Model for predicting evaporation from a row crop during incomplete cover, Water Resour. Res. 8 (1972), pp. 1204-1213.
Rosenberg et al., $1983 \rightarrow$ N. J. Rosenberg, B. L. Blad, and S. B. Verma, Microclimate: The Biological Environment (2nd ed.), John Wiley and Sons, New York, NY (1983) 495 pp. .

Sauer et al., $1998>$ T. J. Sauer, J. L. Hatfield, J. H. Prueger, and J. M. Norman, Surface energy balance of a corn residue-covered field, Agric. For. Meteorol. 89 (1998), pp. 155-168.

Schneekloth et al., 1991 J. P. Schneekloth, N. L. Klocke, G. W. Hergert, D. L. Martin, and R. T. Clark, Crop rotations with full and limited irrigation and dryland management, Trans. ASAE 34 (1991), pp. 2372-2380.

Shukla and Mintz, 1982 J. Shukla and Y. Mintz, Influence of land-surface evapotranspiration on the earth's climate, Science 215 (4539) (1982), pp. 1498-1501.

Slatyer and McIlroy, $1961>$ R. O. Slatyer and I. C. McIlroy, Practical Microclimatology, CSIRO, Melbourne, Australia (1961).

Steduto, $1996>$ P. Steduto, Water use efficiency. In: L. S. Pereira, R. A. Feddes, J. R. Gilley, and B. Lesaffre, eds., Sustainability of Irrigated Agriculture, NATO ASI Series E: Applied Sciences, Kluwer Academic Publishers, Dordrecht, NLDS (1996), pp. 193-209.

Steffey et al., 1999 K. L. Steffey, M. E. Rice and M. E. Gray, Identification of insects and diagnosis of injury, in Handbook of Corn Insects, Entomological Society of America, Lanham, Maryland (1999) pp. 22-43.

Suyker and Verma, 1993 A. E. Suyker and S. B. Verma, Eddy correlation measurements of $\mathrm{CO}_{2}$ flux using a closed-path sensor: theory and field tests against an open-path sensor, Boundary-Layer Meteorol. 64 (1993), pp. 391-407.

Suyker et al., 2003 A. E. Suyker, S. B. Verma, and G. G. Burba, Interannual variability in net $\mathrm{CO}_{2}$ exchange of a native tallgrass prairie, Global Change Biol. 9 (2003), pp. 1-11.

Suyker and Verma, 2008 A. E. Suyker and S. B. Verma, Interannual water vapor and energy exchange in an irrigated maize-based agroecosystem, Agric. For. Meteorol. 148 (2008), pp. 417-427.

Tanner and Jury, 1976 C. B. Tanner and W. A. Jury, Estimating evaporation and transpiration from a row crop during incomplete cover, Agron. J. 68 (1976), pp. 239-243.

Tanner and Sinclair, $1983 \longrightarrow$ C. B. Tanner and T. R. Sinclair, Efficient water use in crop production: research or re-search?. In: H. M. Taylor et al., Editors, Limitations to Efficient Water Use in Crop Production, ASA, Madison, WI (1983), pp. 1-27.

Verma et al., 2005 S. B. Verma, A. Dobermann, K. G. Cassman, D. T. Walters, J. M. Knops, T. J. Arkebauer, A. E. Suyker, G. G. Burba, B. Amos, H. Yang, D. Ginting, K. G. Hubbard, A. Gitelson, and E. A. Water-Shea, Annual carbon dioxide exchange in irrigated and rainfed maize-based agroecosystems, Agric. For. Meteorol. 131 (2005), pp. 77-96.

Webb et al., 1980 E. K. Webb, G. I. Pearman, and R. Leuning, Correction of flux measurements for density effects due to heat and water vapor transfer, Quart. J. R. Meteorol. Soc. 106 (1980), pp. 85-100.

Wilhelm et al., 2004 W. W. Wilhelm, J. M. F. Johnson, J. L. Hatfield, W. B. Voorhees, and D. R. Linden, Crop and soil productivity response to corn residue removal: a literature review, Agron. J. 96 (2004), pp. 1-17.

Wofsy et al., $1993 \rightarrow$ S. C. Wofsy, M. L. Goulden, J. W. Munger, S. M. Fan, P. S. Bakwin, B. C. Daube, S. L. Bassow, and F. A. Bazzaz, Net exchange of $\mathrm{CO}_{2}$ in a midlatitude forest, Science $\mathbf{2 6 0}$ (1993), pp. 1314-1317. 